https://doi.org/10.18485/iipe_response2covid19.2021.ch23

\title{
COVID-19 - AN EXCUSE TO AVOID THE RULE OF LAW? THE CASE OF SLOVAKIA ${ }^{1}$
}

\begin{abstract}
Hana Kováčiková2
Abstract: The loss of transparency. This appears to be the first and most immediate consequence brought by COVID-19 to Slovakia from the legal point of view. At the very same time, the loss of transparency causes the loss of proportionality and leads to the breach of the principles of the rule of law and the excessive limitation of the human rights of the population. Slovakia might be the proof of this opinion. During this pandemic, the Slovak authorities have often used the "COVID cover" for a variety of extraordinary measures. For example, legislators adopted or tried to adopt a lot of acts not related to the crisis without usual public discussion and through shortened legislative procedures; public procurers purchased goods and services without competitive tendering and proper justification for the use of direct awarding; measures restricting fundamental rights were adopted by the Public Health Office without legal authorization, etc. The research in this chapter is focused mainly on (not) respecting the principle of proportionality by the Slovak authorities while adopting anti-pandemic measures.

During the research, methods such as doctrinal analysis, deduction, comparison, and synthesis will be applied with the aim of assessing the legal challenges brought by COVID-19 to the Slovak Republic. In this regard, the compliance of adopted measures with the Slovak Constitution and the European Convention on Human Rights will be tested to find out answers to the following research question: Have the measures adopted by the Slovak authorities complied with the principles of the rule of law?
\end{abstract}

Keywords: COVID-19, rule of law, proportionality, human rights, state measures

\footnotetext{
${ }^{1}$ This contribution presents some results from research projects: Jean Monnet No. 620758EPP-1-2020-1-SK-EPPJMO-CoE: The Rule of Law in the European Union and APVV-PPCOVID-20-0026: Are we recovering from the Covid-19 pandemic? - the social, economic, and legal perspectives of the pandemic crisis.

${ }^{2}$ Associate professor, Institute of European Law, Comenius University in Bratislava, Faculty of Law, Šafárikovo nám. 6, 81000 Bratislava, Slovakia, hana.kovacikova@flaw.uniba.sk
} 


\section{THE STATE OF EMERGENCY - GENERAL LEGAL ISSUES}

"Even in an emergency situation, the rule of law must prevail" (Council of Europe, 2020a, p. 3). Generally, under the rule of law, the public administration shall "always act within the constraints set by law, in accordance with the values of democracy and fundamental rights, and under the control of independent and impartial courts" (Mokrá, Juchniewicz, Modrzejewksy, 2019, p. 185). The imperative of compliance of any measure adopted by the state with the rule of law increases its importance since an unexpected emergency situation sometimes requires unprescribed but quick solutions. The COVID-19 pandemic hit our world in an unprecedented way ${ }^{3}$, and states have chosen various solutions in their attempts to protect the lives and health of their populations.

As the European Court of Human Rights (ECtHR) stated a long time ago in Ireland v. the UK (para. 207), "it is the responsibility of the state to determine whether the life of its nation is threatened by a public emergency and, if so, how far it is necessary to go in attempting to overcome the emergency". States have at their disposal a wide margin of appreciation in this regard. Measures taken to protect the life or health of the population can even redistribute the powers between the state authorities as well as restrict some of the population's nonabsolute human rights. ${ }^{4}$ However, the ECtHR also clearly stated that "states do not enjoy unlimited power in this respect". The essential character of the rule of law should be, therefore, its ubiquity.

A state of emergency usually impacts two main areas: human rights and the exercise of state powers (European Parliamentary Research Service, 2020 p. 5).

The Venice Commission reminds in this regard (Interim Report, 2020, para. 2325 ) that only such shifts in powers comply with the rule of law, which are necessary to help overcome an exceptional situation, lead to a return to normalcy and are limited in time to the period of an emergency situation.

Measures restricting human rights "are strictly limited to what is required by the exigencies of the situation" (Lawless v. Ireland No. 3, para. 22). The judicial

\footnotetext{
${ }^{3}$ To the date of 31 July 2021, WHO confirmed 196553009 COVID positive cases and 4.200.412 deaths (Source: https://covid19.who.int/)

${ }^{4}$ As stated by the Council of Europe (2020a, p. 2), "the right to life, the prohibition of torture and inhuman or degrading treatment or punishment, the prohibition of slavery and servitude, and the rules of nulla poena sine lege and ne bis in idem, as well as the abolishment of the death penalty, shall never be derogated".
} 
power is then responsible for assessing ${ }^{5}$ whether the state is within the limits or has gone beyond the conditions for exceptional derogation of human rights.

Therefore, the requirements of the rule of law are met only when both/any of these measures are established by the law (test of legality), pursue a legitimate aim (test of legitimacy) and are adequate for the crisis with regard to necessity, adequacy, and temporariness (test of proportionality).

The most current help on this matter came from the Council of Europe (CoE), which provided a Toolkit (CoE, 2020a) to help states to handle the COVID-19 pandemic within the framework of the rule of law. It accepts that states adopt various types of extraordinary emergency law but requires constitutional authorisation or at least constitutional compliance. The condition of the temporariness of the measures shall contain not only a requirement for a return to normalcy "as quickly as possible", but when the state of emergency needs to be prolonged, such a necessity for prolongation should be tested and also approved by the parliament. Furthermore, the CoE warns states to give their governments a "carte blanche" when issuing an emergency law and reminds them that emergency measures must be "capable of achieving their purpose with minimal alteration of the normal rules and procedures of democratic decision-making" (p. 4). Finally, it points out the importance of checks and balances even in situations where those are eased due to the necessity to act quickly and efficiently: "Parliaments, however, must keep the power to control executive action, in particular by verifying, at reasonable intervals, whether the emergency powers of the executive are still justified, or by intervening on an ad hoc basis to modify or annul the decisions of the executive." (p. 4).

In this document, the CoE also paid attention to the relevant human rights standards by requiring states to ensure an adequate level of medical care for people deprived of their liberty, and raising attention to severely ill patients, people with disabilities or elderly persons as their "exposure to diseases and the extreme level of suffering may be found incompatible with the state's positive obligation to protect life and prevent ill-treatment" (p. 5).

When talking about privacy and data protection, the CoE warns that "the intrusive potential of modern technologies must not be left unchecked and unbalanced against the need for respect of private life" (p. 7).

\footnotetext{
${ }^{5}$ As pointed out by Mokrá and Kováčiková (2020, p. 89), "the very existence of effective judicial protection by independent courts is the essence of the rule of law".
} 
Finally, it requires the states to thoroughly consider whether derogating antipandemic measures "discriminate unjustifiably between different categories of persons" (p. 7).

The principles and tests described in this part serve as benchmarks when considering the steps taken by the Slovak authorities during the fight against COVID-19 in 2020-2021.

\section{THE SLOVAK PANDEMIC LEGAL FRAMEWORK}

\section{Generally binding emergency law}

Slovakia is a state which had already had the relevant emergency law adopted before the pandemic started. Slovakia has two emergency regimes - an extraordinary situation under the [ordinary] Population Protection Act No. 42/1994 and a [constitutional] state of emergency under the Constitutional Act on the protection of the State No. 227/2002 (CAPS). Both of these regimes are issued by the government through its resolutions. This dual regime provides a mixture of measures introduced both under ordinary legislation and constitutional provisions. However, if those two regimes are applied at the same time, the latter prevails.

Introducing the extraordinary situation enables the adoption of measures such as rescue work by forces and resources from the entire territory where the extraordinary situation was declared, evacuation, emergency supplies and accommodation, or the use of parts of the integrated rescue system (Article 3b:2 of the Population Protection Act). The subsidiarity of extraordinary situations to the state of emergency is expressed by the ban on declaring an extraordinary situation after a state of emergency has been declared. On the other hand, if it was declared earlier than the state of emergency, it would be suspended and a special law would apply (Article 3b:4).

Such a special law grounding the state of emergency (SoE) is represented by the CAPS. However, COVID-19 proved that the legislation was not sufficient and needed to be amended. This was realised at the end of December 2020. ${ }^{6}$ Therefore,

\footnotetext{
${ }^{6}$ The amendment to the CAPS was realised by the Constitutional Act No. 414/2020 Col. of 28 December 2020, which from 29 December 2020 enables prolonging the state of emergency for the next 40 days with the approbation of the parliament. Before this act (during the first wave), the Slovak parliament did not have the power to approve or disapprove the SoE, which contravened the principles described in the above-mentioned Toolkit (2020).
} 
the later, second-wave legislation differs from the first-wave legislation, bringing more transparency and even legality.

The current legislation defines the material conditions (Article 5:1: "if there is or exists an imminent threat to human life and health in a causal link to a pandemic" and "only for the territory affected or immediately endangered"), time scope (Article 5:2: "for the necessary time, for a maximum of 90 days" and may be "prolonged for a further 40 days, even repeatedly" if it is approved by the Parliament), rights, which may be (regarding the necessary extent, the necessary time and gravity of the threat) restricted, and obligations, which shall be imposed by declaring the SoE due to a pandemic (Article 5:4). These include, for example, the right to restrict the inviolability of the person and his privacy by a forced stay at home or by evacuation to a designated place, to impose a labour duty to ensure essential supplies, health care and provision of social services, to restrict the inviolability of the home for the purpose of accommodation of evacuees, to restrict freedom of movement and stay, to restrict or prohibit the right to assembly or association, or to make it conditional on the authorisation.

The government decides on the SoE declaration in the form of a resolution, and such a resolution must be published officially in the Collection of Laws.

\section{Government's COVID-19 reaction}

The first-wave Government's resolution No. 114/2020 on declaring the SoE was not doubted. ${ }^{7}$ Then, the Slovak government used the full range of this regime and declared a state of emergency for 90 days (from 16 March to 13 June 2020).

However, the second-wave Government's resolution No. 587/2020 of 30 September 2020 on declaring the SoE (from 1 October 2020) raised questions about whether material conditions for its declaration were fulfiled (it did not contain any justification for its adoption) and whether it complies with the Constitution and its principles (of legality and the rule of law). Therefore, a group of Members of Parliament (MPs) and even the General Prosecutor (GP) filed an application to the Constitutional Court of the Slovak Republic (CCSR) requesting judicial control of this resolution. ${ }^{8}$

\footnotetext{
${ }^{7}$ On the other hand, measures adopted by state authorities (discussed in the following part) on the basis of this resolution and during the first wave, raised a lot of questions relating to the respect of human rights and their conformity with the Slovak Constitution.

${ }^{8}$ Pursuant to Article 129:6 of the Constitution, the CCSR decides whether the decision on the declaration of a state emergency and subsequent decisions comply with the constitution and constitutional law. Such a judgement of the CCSR must be adopted within 10 days of the filing of the application. (Article 196:1 of the Constitutional Court Act).
} 
The CCSR, in its judgement PL. ÚS 22/2020 (para. 43), held in this regard that the "assessment of whether the material conditions prescribed by the law are met, and whether the declaration of the SoE is necessary, requests, besides other things expert, conceptual and also political considerations. The government (as the highest executive authority with wide and relevant powers) is therefore in a better position than the CCSR to assess such circumstances, and it is democratically responsible for the consequences of its (positive or negative) decision." As further explained by the CCSR, its task is not to consider the optimality of the SoE, but strictly only the proportionality of the government's activities which restrict human rights and impose obligations.

However, although the CCSR considered that this resolution met formal and procedural aspects of the principle of legality, at the same time, it pointed out the lowered level of transparency connected with the missing justification of the resolution (para. 52: "The constitutional act does not explicitly require the justification of the SoE to be included in the resolution."). On the other hand, when adopting the resolution on declaring the SoE, it is appropriate, regarding the principle of legal certainty, that the resolution should contain (at least) a brief justification, so the reason and object of the SoE shall be naturally ascertainable from the factual, social, and legal context, and arbitrariness will be excluded", and para 56: "the government's resolution on the SoE should contain a justification for the purpose of its documentary reviewability and trackability of a clear link to subsequent acts relating to the SoE under the Constitutional Act on Protection of the State.").

This second-wave SOE was four times prolonged (by the Government's resolutions No. 807/2020 of 29 December 2020, No. 77/2021 of 5 February 2021, No. 160/2021 of 17 March 2021 and No. 215/2020 of 26 April 2021) to a total length of 226 days.

The third prolongation resolution (No. 160/2021) also faced the constitutional control of the CCSR, as both the group of MPs and the GP considered it unjustified and contravening the principles of legality and the rule of law.

During the review, the CCSR, in its decision PL. ÚS 2/2021 (para. 76) stressed that "its suspicion in the assessment of (repeatedly) prolonged SoE is higher due to the objective fact of the passage of time and requires a stricter consideration than in the case of a [newly] declared SoE. However, the strictness is substantially determined by the severity and nature of the continuing threat".

Considering the missing justification of prolongation, the CCSR confirmed (para. 85 ) its earlier opinion in PL. US $22 / 2020$ by saying that it did not affect the compliance of the contested resolution with the Constitution or constitutional law as the "recapitulation of the pandemic situation, which served as the information 
basis for the decision of the government on repeated prolongation of the SoE [provided during the process also to the CCSR] sufficiently constitutionally justifies this resolution" (para. 84).

Considering the length of the 40-day prolongation, the CCSR reasoned (para. 88) that the necessity of prolongation cannot depend only on the state of affairs at the time of the decision but also on the reality of the threat of a possible deterioration of this state.

Finally, the CCSR held that it would be possible to consider the non-compliance of the prolongation of the SoE with the constitutional law only if it is undoubted that we are not confronted with an unfortunate fact - the factual circumstance of a pandemic endangering the lives and health of persons. "This is not the case now, and we can only hope that it will happen soon."). As a result, it confirmed the compliance of this resolution with the Constitution.

Upon the basis of the declaration of the SoEs, ministries and other state authorities were empowered to adopt relevant anti-COVID measures. The establishment of this regime enabled the Slovak government to use predetermined exceptional and/or extraordinary measures (including the restriction of some fundamental rights).

\section{Shifting of power to other state players}

The specific role in the COVID-19 battle plays the Public Health Authority of the Slovak Republic (PHA), ${ }^{9}$ which has become the key authority to adopt the most relevant measures dealing with COVID-19.

The legal grounds for its action can be found in the Public Health Protection Act No. 355/2007. The PHA is led by the Main Hygienist and among its main tasks are planning, coordination, and setting the scope of the control of infectious diseases (Article 5:4:c) and ordering measures for the prevention of diseases or threats to public health beyond the regional scope (Article 5:4:k). Such measures may also include isolation at home or in a medical or other designated facility, increased medical surveillance or quarantine (Article 12:2:f).

If there is a threat to public health, the PHA and regional PHA shall identify and react to new and endangering infectious diseases and other threats (Article 48:3).

\footnotetext{
${ }^{9}$ The PHA is not listed in the official list of central administration authorities contained in Act No. 575/2001 Col. on the organization of central administration. By its character, it is a state budgetary organization connected to the Ministry of Health and is competent to act on the whole territory of the Slovak republic.
} 
The PHA orders measures by which it may (among others) prohibit or restrict the contact of a part of the population with the rest of the population (Article 48:4:c), mass events (Article 48:4:d), or impose forced isolation of a person suffering from an infectious disease or suspected of having a disease or quarantine of a person suspected of having a disease who refuses ordered home isolation or isolation in a medical or another facility (Article 48:4:n).

It seems that PHA's measures are the most problematic in terms of the proportionality of the state's intervention in human rights, especially during the first wave.

In September 2020, the GP issued the Prosecutor's alert by which he declared that all COVID-19 measures adopted by the PHA's public orders from the time of the declaration of the SoE (16 March 2020) relating, for example, to the state border regime, forced isolation, the duration of the laboratory diagnostics of COVID-19, hygienic requirements inside and outside of facilities, and the organisation of mass events, were illegal (but not void). The GP reasoned that the PHA was not a part of the crisis board of the state, it was not even a central administration body, and was not entitled to adopt such measures as during the SoE, since (according to the CAPS) relevant anti-COVID measures should only be ordered directly by the Ministry of Health. Furthermore, the PHA's public orders had a legally unclear character, as the PHA neither recognised whether they were individual acts nor generally binding law. ${ }^{10}$ Moreover, as they did not need to be published in the Collection of Laws, they were not transparent and accessible to all addressees. Finally, the CAPS created a special constitutional legal regime different from the activities of the PHA covered by the [ordinary] Public Health Protection Act.

The findings of the General Prosecutor were reflected in Act No. 286/2020 of 14 October 2020, which amended the Public Health Protection Act and empowered the PHA to act even in times of the SoE.

\section{FUNDAMENTAL RIGHTS V. ANTI-PANDEMIC MEASURES}

As accurately pointed out by the European Parliamentary Research Service (EPRS) in its study $(2020$, p. 7), the rights that are likely to be affected during a pandemic are those connected to freedom of movement, ${ }^{11}$ rights to education,

${ }^{10}$ The General Prosecutor called it, with reference to the CCSR's case law, a "hybrid act" not recognised in the official Slovak structure of legal acts.

${ }^{11}$ See also Mokrá, Fridrich, 2016 for the impact of limited freedom of movement and human rights. 
rights to property, and freedom to conduct business, as well as the rights of assembly, expression, protection of personal data, or political rights.

Since the extent of this chapter is limited, only the most discussed measures of the Slovak authorities will be analysed. They are related to forced state isolation, electronic monitoring through mobile phones, and mandatory nationwide testing of the population. ${ }^{12}$

\section{Forced state isolation (the right to liberty)}

Pursuant to Article 5:1:e of the ECHR, everyone has the right to liberty ${ }^{13}$ and security of person, except in the case of lawful detention for the prevention of the spread of infectious diseases. By its public orders No. OLP/3012/2020, No. 3172/2020, No. OLP/3353/2020 and No. OLP/3992/2020, the PHA ordered every person who entered Slovakia from 6 April 2020 onwards to undergo forced isolation in the facilities designated by the state for the period of time necessary to exercise the COVID-19 laboratory diagnostics. After a negative result, such a person was ordered to undergo home isolation for the length of 14 days, together with the other members of such person's household. ${ }^{14}$

The aspect of legality was briefly analysed in the previous part - the General Prosecutor considered the mentioned public orders of the PHA illegal, and the author agrees with this opinion. However, other questions relating to the protection of human rights are relevant too.

\footnotetext{
12 However, constitutional and human rights doubts are raised even in relation to the right to education (children from the marginalised groups of the population did not have sufficient access to education during lockdowns), the right to liberty and privacy (social care homes and hospitals were closed and people stayed there for many months and even died without the possibility to see their families for the last time), the right to have proper health care (seriously ill people were denied surgeries or sufficient health treatment, as serious numbers of operations were postponed for an unspecified time), and others.

${ }^{13}$ The CCSR defined personal liberty as the unrestricted movement of a person who, at his/her own discretion, may reside in a certain place or leave that place freely (III. ÚS 204/02-47, p. 13).

${ }^{14}$ This measure also has exceptions (e. g., for pregnant women, people older than 75 years, and others), but this fact is not relevant for the purpose of this chapter. This regime was eased by the last order with the option to alter forced state isolation by the activation of a mobile application able to track and monitor the home isolation and definitely cancelled by the public order No. OLP/4739/2020 of 9 June 2020 when the SoE ended.
} 
When assessing the proportionality of the restriction of the right to liberty through forced state isolation, it is necessary to bear in mind the criteria established by the ECtHR in Witold Litwa v. Poland (para. 78): "The necessary element of the "lawfulness" of the detention within the meaning of Article $5 \S 1$ (e) is the absence of arbitrariness. The detention of an individual is such a serious measure that it is only justified where other, less severe measures have been considered and found to be insufficient to safeguard the individual or public interest which might require that the person concerned be detained. That means that it does not suffice that the deprivation of liberty is executed in conformity with national law, but it must also be necessary in the circumstances". Enhorn v. Sweden (para. 44) states: "the lawfulness of the detention of a person for the "prevention of the spread of infectious diseases" is whether the spread of the infectious disease is dangerous to public health or safety, and whether the detention of the person infected is the last resort in order to prevent the spread of the disease because less severe measures have been considered and found to be insufficient to safeguard the public interest."

In light of those principles, it is necessary to start by distinguishing between the terms of isolation and quarantine. Pursuant to the Public Health Protection Act, the term "isolation" means the separation of persons suffering from infectious disease during their infectivity from other persons in order to prevent the spread of an infectious disease. The term "quarantine" relates only to the person suspected (not suffering) of infectious disease, to whom are dedicated lighter measures (e.g., increased medical surveillance, but not isolation). The PHA, by its blanket order to isolate all (both infectious and not-infectious) persons in forced state isolation in designated facilities, which were often hundreds of kilometres from the homes of affected persons, did not fulfil the requirements of proportional measures and breached the rule of law.

It is worth mentioning (according to the author's opinion) the rather alibi approach of the CCSR to this question. Despite the tens of applications in this regard, it denied all of them with the reasoning that such public orders represent "hybrid acts" with elements of an individual administration act as well as elements of a generally binding act, which requires the review of administrative courts. Moreover, except for the fact that the Slovak legal order officially did not recognise "hybrid acts", at the time of the decisions of the CCSR on these applications, all deadlines for administration actions were missed.

\section{Geo-tracking and excessive procession of personal data (the right to privacy)}

The CCSR in case PL. ÚS 13/2020 subjected to constitutional control those articles of the Telecommunication Act No. 351/2001 which impose obligations on 
telecommunication operators to process the data of their users and provide these data to the PHA upon its request, even without the consent of the users. The CCSR, by its decision of 13 May 2020, preliminary suspended the legal force of the contested act. Firstly, it reminded (para. 69) that the purpose of the right to privacy is to "prevent the public authorities from interfering in the conduct of the individual beyond what is necessary and managing his/her private life too disproportionally." During the assessment, the CCSR prioritized the certainty of the legal framework and the guarantees against abuse of using the data. The CCSR pointed out (para. 81) that the widespread preventive collection of personal data presents a "particularly serious interference" or "serious interference" with the right to privacy and the right to protection of personal data. The CCSR considered contested data collection and its subsequent use to be set up so widely that (para. 85) it could be used almost freely for any purpose in the context of a pandemic, as it was formulated as a kind of a general clause for various uses. The CCSR stressed that given the severity of the interference with the right to privacy and the protection of personal data, this type of personal wording cannot be allowed in a democratic society.

However, before the CCSR could adopt its final matter-in-fact judgement, in this case, the Telecommunication Act was changed (to reflect the findings of the CCSR), and the CCSR stopped the proceedings.

\section{Mandatory nationwide screening with tests for COVID-19}

The government, besides other measures, by its already mentioned Resolution No. 160/2021, ordered a curfew from 20 March 2021 to the end of the SoE. The exemptions from the curfew were defined. However, they were conditioned on the necessity of endurance of antigen testing for COVID-19. The GP filed an application to the CCSR to consider the compliance of this measure with the Constitution and disproportionate interference with the person's integrity (it is questionable whether the subjecting of testing, which is forced under the threat of job loss, a ban on accompanying children to kindergarten or primary school, or a ban on going to nature, can be considered as consent). As the CCSR held in PI. ÚS. 13/2020, "especially in vertical relations, if the consent was obtained under the threat of a negative consequence, it is not possible to consider it voluntary". However, in PL. ÚS 2/2021, it specified that "examination of the testing obligation requires that in the practice of the SoE it cannot be ruled out that the government's effort to strictly respect the necessity of an approved restriction of one human right will secondarily invade another fundamental right (restriction of freedom of movement and, in this line, the integrity of person), which is or is not included in the exhaustive enumeration pursuant to Article 5:3-4 CAPS. There could be a large number of 
prescribed situations, and if the government was always limited by the requirement that it could use the restriction only if it did not (albeit indirectly) interfere with another fundamental right or freedom, the flexibility and effectiveness of its decision-making in crisis situations would be so limited that it is debatable whether the meaning of restricting fundamental rights and freedoms in crisis situations would not be substantially denied." The CCSR, therefore, perceived the conditionality of exemption on the negative result of the test as an attempt by the government to find a solution that respects the necessity of restricting freedom of movement at the level of the constitutional legal requirement.

Therefore, mandatory testing in this context was not considered a breach of human rights.

\section{CONCLUSION}

The above-mentioned analysis is not exhaustive nor comprehensive as the extent of this chapter is limited. However, even from this brief insight, we can conclude that the Slovak response to the COVID-19 pandemic surely challenged the principle of the rule of law and, in some cases, raised doubts about its conformity with the Constitution and human rights guaranteed by the ECHR. Existing legislation proved to be insufficient and needed to be improved. In its attempt to fight the pandemic, Slovakia managed to go even beyond the edge of legality - not only with the mentioned measures, but also with others, not discussed in this chapter (connected with the widespread forced isolation of Romas, denying the right to education or denying adequate health care).

However, such an assessment can be deducted only from the academic analysis of adopted measures, as the CCSR did not issue any final decision on this matter. In this regard, the author found 252 decisions of the CCSR filtered with the "COVID" term. Even in cases where the CCSR preliminary found an inconsistency with the Constitution due to the amendment or withdrawal of such a measure, the CCSR could not decide on the merits of such an amended or no longer valid act. On the other hand, the flexibility with which the legislator reflected on the findings of the CCSR means that it wanted to comply with democratic principles.

The answer to the question of whether the measures adopted by the Slovak authorities have complied with the principles of the rule of law is therefore not monochromatic. Even from the brief insight contained in this chapter, one can deduce that some of them have not. On the other hand, those of the most importance (e.g., declaring the SoE and its prolongation) passed the test of compliance. The good sign is that the Slovak Republic, even after declaring the SoE, has reflected the soft law provided by the Council of Europe and the Venice Commission. 
For the third wave of COVID-19, which is coming (as the experts say), it is crucial to learn lessons from previous waves and avoid mistakes and misconduct that appeared during this time.

The final recommendation is similar to that of the Slovak National Centre of Human Rights (2020, p. 144): implement all basic democratic principles and guarantees for all COVID-19-related measures, strictly distinguish between already infectious and just suspected individuals, and set restrictions on one human right with the greatest regard for the other.

\section{REFERENCES}

Council of Europe. (2020). Respecting democracy, rule of law and human rights in the framework of the COVID-19 sanitary crisis. A toolkit for member states, retrieved from https://rm.coe.int/sg-inf-2020-11-respecting-democracy-ruleof-law-and-human-rights-in-th/16809e1f40. Accessed 10 July 2021.

Council of Europe. (2020). Democratic Governance and COVID-19 Report. Council of Europe Publishing, Strasbourg, retrieved from https://rm.coe.int/cddg-202020e-final-reportdemocraticgovernancecovid19-for-publication-/1680aObeed/. Accessed 15 July 2021.

European Parliamentary Research Studies. (2020). States of emergency in response to the coronavirus crisis. Normative response and parliamentary oversight in EU Member States during the first wave of pandemic. European Union, Brussels. ISBN: 978-92-846-7547-0, doi: 10.2.861/892605, retrieved from https:// www.europarl.europa.eu/RegData/etudes/STUD/2020/659385/EPRS_STU(202 0)659385_EN.pdf. Accessed 15 July 2021

European Union Agency for Fundamental Rights. (2021). Coronavirus Pandemic in the EU - Fundamental Rights implications: Vaccine Rollout and Equality of Access in the EU. Publication Office of the European Union, Luxembourg. ISBN: 978-92-9461-337-0, doi: 10.2811/604585, retrieved from https://op.europa. eu/sk/publication-detail/-/publication/2b2a97a6-ce4c-11eb-ac72-01aa75ed 71a1/language-en/format-PDF/source-search . Accessed 12 July 2021

Mokrá, L.- Caroccia, R. (2020). The court of justice's contribution to the development of the principle of transparency, Evropsko zakonodavstvo, 19(72), pp. 5-15.

Mokrá, L.- Kováčiková, H. (2020). Efficiency of justice system as the principle applied in the rule of law framework in the European Union, In: Bratislavské právnické fórum 2020: právne výzvy pre novú Európsku komisiu. (pp. 87-100). Bratislava, Právnická fakulta UK, retrieved from https://www.flaw.uniba.sk/fileadmin/ 
praf/Veda/Zborniky/2020-12-30_Bratislava_Legal_Forum2020.pdf. Accessed 20 July 2021

Mokrá, L., Juchniewicz, P., Modrzejewski, A. (2019). Rule of law in Poland- integration or fragmentation of common values?, European Journal of Transformation Studies. 7(2), pp. 177-188. ISSN (online) 2298-0997, retrieved from https://r. donnu.edu.ua/handle/123456789/646. Accessed 26 July 2021

Mokrá, L., Fridrich, B. (2016). L'udské práva. [Human Rights]. Bratislava. Výskumné centrum Slovenskej spoločnosti pre zahraničnú politiku, 59 p. ISBN 978-8089540-69-3

Prokurátorské fórum. (2020). Mimoriadna situácia vs. núdzový stav - dva režimy pravidiel fungovania štátu. [Extraordinary situation v State of emergency - two regimes of the functioning of the state]. 10 November 2020, retrieved from https://beta.ucps.sk/mimoriadna-situacia-vs-nudzovy-stav-dva-rezimy-pravidielfungovania-statu. Accessed 10 July 2021

Slovenské národné stredisko pre ludské práva. (2020). Správa o dodržiavaní ludských práv vrátane zásady rovnakého zaobchádzania v Slovenskej republike [Report on Human Rights observance 2020 including the principle of non-discrimination in Slovak republic]. ISBN 978-80-99917-13-3, retrieved from http://www.snslp. sk/ wp-content/uploads/Sprava-o-LP-v-SR-za-rok-2020-1.pdf. Accessed 12 July 2021.

Ústavný súd Slovenskej republiky (2020). Núdzový stav v reakcii na krízu koronavírusu: situácia v niektorých členských štátoch III. [State of emergency as a reaction to the coronavirus crisis - situation in some states III.], retrieved from https://www.ustavnysud.sk/documents/10182/132068014/Analyza+EU+k + nudzovemu+stavu+1II.pdf/a645fdfa-9b02-4467-98c9-69732e5387f1. Accessed 11 July 2021

Venice Commission. (2020) Interim report. Opinion No. 995/2020 of October 2020. Strasbourg, retrieved from https://www.venice.coe.int/webforms/documents/? pdf $=C D L-A D(2020) 018-$ e. $_{\text {. Accessed }} 20$ July 2021

\section{Legal acts}

Act of the National Council of the Slovak Republic No. 42/1994 Col. on civil protection of the population. Collection of Laws of the Slovak republic No. 11 (1994).

Constitutional Act of the National Council of the Slovak Republic No. 227/2002 Col. on the protection of the State during the war, state of war, exceptional state and state of emergency. Collection of Laws of the Slovak republic No. 97 (2002).

Constitutional Act of the National Council of the Slovak Republic No. 414/2020 Col. on amendment and supplement of the Constitutional Act of the National 
Council of the Slovak Republic No. 227/2002 Col. on the protection of the State during the war, state of war, exceptional state and state of emergency, as amended. Collection of Laws of the Slovak republic 414 (2020).

Act of the National Council of the Slovak Republic No. 355/2007 Col. on protection, support and development of public health and amendment of other laws. Collection of Laws of the Slovak republic No. 154 (2007).

Public order of the Public Health Authority of the Slovak Republic No. OLP/3012/ 2020 of 4 April 2020 for the case of the threat to public health

Public order of the Public Health Authority of the Slovak Republic No. OLP/3172/ 2020 of 17 April 2020 for the case of the threat to public health

Public order of the Public Health Authority of the Slovak Republic No. OLP/3353/ 2020 of 24 April 2020 for the case of the threat to public health

Public order of the Public Health Authority of the Slovak Republic No. OLP/4203/ 2020 of 20 May 2020 for the case of the threat to public health

Resolution of the Government of the Slovak Republic No. 111 of 11 March 2020 to the proposal on declaration of emergency situation in relation to the 2 nd degree threat to public health due to COVID-19 disease caused by the SARS-CoV-2 corona virus in the territory of the Slovak Republic

Resolution of the Government of the Slovak Republic No. 114 of 11 March 2020 to the proposal on declaration of the state of emergency

Resolution of the Government of the Slovak Republic No. 366 of 10 June 2020 to the proposal on removal of the state of emergency proclaimed by the Resolution of the Government of the Slovak Republic No. 114 of 15 March 2020

Resolution of the Government of the Slovak Republic No. 807 of 29 December 2020 prolongation of the state of emergency

Resolution of the Government of the Slovak Republic No. 77 of 5 February 2021 on prolongation of the state of emergency

Resolution of the Government of the Slovak Republic No. 160 of 17 March 2021 on prolongation of the state of emergency

Resolution of the Government of the Slovak Republic No. 215 of 26 April 2021 on prolongation of the state of emergency

\section{Decisions}

Judgement of the European Court of Human Right in case of Enhorn v. Sweden (Application No. 56529/00) of 25 January 2005 
Judgement of the European Court of Human Right in case of Witold Litwa v. Poland (Application No. 26629/95) of 4 April 2000

Judgement of the European Court of Human Right in case of Ireland v. The United Kingdom (Application No. 5310/71) of 18 January 1978

Judgement of the European Court of Human Right in case of Lawless v Ireland No. 3 (Application No. 332/57) of 18 July 1961

Judgement of the Constitutional Court of the Slovak republic No. PL. ÚS 2/2021 of 31 March 2021, ECLI:SK:USSR:2021:PL.US.2.2021.3

Judgement of the Constitutional Court of the Slovak republic No. PL. ÚS 22/2020 of 14 October 2020, ECLI:SK:USSR:2020:PL.US.22.2020.2

Judgement of the Constitutional Court of the Slovak republic No. PL. ÚS 13/2020 of 13 May 2020, ECLI:SK:USSR:2020:PL.US.13.2020.1

Judgement of the Constitutional Court of the Slovak republic No. III. ÚS 204/02 of 22 January 2004

Prosecutor's alert to illegal conduct of public administration authority of the General Prosecution of the Slovak republic of 22 September $2020 \mathrm{No} \mathrm{VI/3} \mathrm{Gd}$ 174/20/1000-16. 